\title{
Vitamin A deficiency and small intestinal secretory function in the rat
}

\author{
H Nzegwu, R J Levin
}

\begin{abstract}
The influence of vitamin $A$ on the functions of the small intestine was examined in rats made vitamin $A$ deficient for $\mathbf{4 0}$ days by feeding a special diet after weaning and in pair fed vitamin A deficient rats that were given supplementary vitamin A (240 IU/day) in their drinking water. The basal and stimulated electrogenic secretory and absorptive functions of the jejunum and proximal and distal ileum removed from these rats were examined in vitro using the short circuit current as the index of transport activity. The basal short circuit current in the jejunum and proximal ileum was not significantly different but that of the distal ileum was lower. Electrogenic glucose transfer was not significantly affected by the vitamin deficiency. Cholinergic stimulation using the M1/M2 agonist bethanechol showed a greatly enhanced electrogenic secretion in the jejunum of the deficient rats while secretion stimulated by dibutyryl cyclic adenosine monophosphate was significantly greater in their distal ilea compared with the supplemented group. The vitamin deficiency also disrupted the normal higher/lower hierarchical pattern of transport activity between the proximal and distal ileum. The enhanced secretory activity of the vitamin A deficient small intestine offers a putative explanation for the well known relation between vitamin $\mathbf{A}$ deficiency and diarrhoea found in humans.
\end{abstract}

Vitamin A deficiency has been claimed to rank worldwide among the most common of dietary deficiencies. ${ }^{1}$ In humans it is usually associated wth diarrhoea, but despite many observational, clinical, interventional, and field studies it is still unclear whether the deficiency is the direct cause of the diarrhoea or merely a consequence of poor nutritional health. ${ }^{23}$ While there have been a few animal studies on the effects of vitamin A deficiency on the small intestine, these have focused either on changes in the population dynamics of the enterocytes, such as the decrease in number of goblet cells, ${ }^{+7}$ an increased cell cycle time coupled with an impaired migration rate out of the jejunal crypts, ${ }^{8}$ or on biochemical changes in nuclear RNA and protein synthesis $^{4910}$ and the enzymes alkaline phosphatase and $\mathrm{Na}^{+}-\mathrm{K}^{+}$adenosine triphosphatase." Apart from a brief note by Kancha and Anasuya ${ }^{12}$ that vitamin A deficiency enhanced in vitro the duodenal transfer of calcium and the jejunal transfer of oxalate, there have been no investigations on the absorptive or secretory functions of the small and large intestine in vitamin A deficiency. The present study was devised to establish whether vitamin A deficiency by itself influenced the secretory mechanisms of the intestine in rats. Because vitamin A deficiency reduces food intake ${ }^{13}$ the use of pair fed controls is essential as a reduction in food intake is now known to induce hypersecretory activity in both small and large intestine ${ }^{14-17}$ and rectum in the rat. ${ }^{18}$ This paper describes the secretory behaviour of the rat small intestine in vitamin $A$ deficiency. A preliminary report has been published. ${ }^{19}$

\section{Methods}

\section{ANIMALS AND DIET}

Weanling 3 week old male albino rats (weight approximately $80 \mathrm{~g}$ ) of the Sheffield strain were divided into five groups. Group 1 was fed a commercially supplied vitamin A deficient diet (diet ssDii from SDS Diets, England) ad libitum and had free access to water. The diet contained casein (15\%), rice starch (35\%), safflower oil (10\%), solkafloc (a bulking agent) (10\%), icing sugar (25\%), and a mixture of vitamins (excluding vitamin A) and essential minerals $(5 \%)$ and was quoted as having a retinol concentration of $0 \mathrm{mg} / \mathrm{kg}$ diet by analysis. The diet was fed for 40 days and the food intake of the rats was measured daily. Group 2 was pair fed the vitamin A deficient diet using the food intake values of group 1 but had a soluble preparation of vitamin A dissolved in their drinking water (Rovimix A 500W, Roche Products) such that their intake approximated to 80 IU vitamin A/ day. Similarly, group 3 was also pair fed on the vitamin A deficient diet according to the intake of group 1 but had an intake of approximately $240 \mathrm{IU}$ vitamin A per day in their drinking water. Group 4 was pair fed the standard CRM pelleted diet used in all our previous studies (Diet CRM Labsure, London, containing 1500 IU vitamin $\mathrm{A} / \mathrm{kg}$ diet) while group 5 comprised age matched controls fed the standard CRM pelleted diet ad libitum. All the rats were housed in plastic cages and were kept at $20(1)^{\circ} \mathrm{C}$ and $72 \%$ humidity with the lights on from $530 \mathrm{am}$ until $630 \mathrm{pm}$. The food intakes of the vitamin A deficient group are shown in Table I for days 1, 10, 20, 30 and 40.

\section{IN VITRO PREPARATION}

On the day of use (after 40 days on the diets) the rats were anaesthetised with intraperitoneal pentobarbitone (May \& Baker; $60 \mathrm{mg} / \mathrm{kg}$ body weight). On achieving surgical anaesthesia, a midline incision was made and the mid-jejunum, some $40-45 \mathrm{~cm}$ from the ligament of Treitz, identified. A $5 \mathrm{~cm}$ length of this area was removed, cut open, and mounted as a flat sheet
W10 2TN

H Nzegwu

Correspondence to:

Dr R J Levin.

Accepted for publication

3 December 1990 
TABLE I Food intake (g/rat/day) on day 1, 10,20, 30, and 40 of the study. Results are mean $(S E)$

\begin{tabular}{|c|c|c|c|c|c|}
\hline & \multicolumn{5}{|c|}{$\begin{array}{l}\text { Food intake (g/rat/day) } \\
\text { on day: }\end{array}$} \\
\hline & 1 & 10 & 20 & 30 & 40 \\
\hline \multirow{2}{*}{$\begin{array}{l}\text { Group 1: vitamin A deficient }(n=26) \\
\text { Group 2: vitamin A deficient }+80 \text { IU } \\
\text { vitamin A/day }\end{array}$} & $2 \cdot 4(0.2)^{2}$ & $7(0 \cdot 7)^{b}$ & $7 \cdot 7(0.5)^{c}$ & $8.2(0.5)^{d}$ & $9(0.8)^{c}$ \\
\hline & PF & PF & PF & PF & PF \\
\hline \multirow{3}{*}{$\begin{array}{l}\text { Group 3: vitamin A deficient }+240 \\
\text { IU vitamin } A / \text { day } \\
\text { Group 4: CRM pair fed } \\
\text { Group 5 CRM age matched, fed ad } \\
\text { libitum }(n=22)\end{array}$} & PF & PF & PF & PF & $\mathrm{PF}$ \\
\hline & $\mathrm{PF}$ & $\mathrm{PF}$ & $\mathrm{PF}$ & $\mathrm{PF}$ & $\mathrm{PF}$ \\
\hline & - & - & - & - & $24(0.5)^{f}$ \\
\hline
\end{tabular}

Kruskal-Wallis analysis of variance followed by Conover's multple $t$ test were used to identify the signifcant values. a $v \mathrm{~b} ; \mathrm{a} v \mathrm{c} ; \mathrm{a} v \mathrm{~d} ; \mathrm{a} v \mathrm{e} ; \mathrm{e} v \mathrm{f}$ are all significant at $\mathrm{p}<0 \cdot 001$. $\mathrm{PF}=$ pair fed. signifcant values. a $v$
$\mathrm{CRM}=$ standard diet
A Type 500W) was a gift from Roche Products, Welwyn Garden City, England.

STATISTICAL ANALYSIS

All the results are shown as the mean (SE). For statistical comparisons the unpaired Student's $t$ test with 0.05 as the level of significance was used. When multiple comparisons were needed the Kruskal-Wallis analysis of variance was used followed by Conover's multiple $t$ test to delineate specific differences. ${ }^{24}$

\section{Results}

between two identical chambers as described previously. ${ }^{14}$ Similarly mounted was a $5 \mathrm{~cm}$ segment of ileum $(15-20 \mathrm{~cm}$ aboral from the ileocaecal junction) and a $5 \mathrm{~cm}$ segment of distal ileum (removed aboral from the ileocaecal junction). The segments were incubated at $38^{\circ} \mathrm{C}$ in bicarbonate saline gassed with $95 \% \mathrm{O}_{2} 5 \%$ $\mathrm{CO}_{2}$. The tissue potential difference (in $\mathrm{mV}$ ), short circuit current $\left(\mu \mathrm{A} / \mathrm{cm}^{2}\right.$ serosal area), and the tissue resistance (ohms $/ \mathrm{cm}^{2}$ serosal area) were all obtained by a previously published standard technique. ${ }^{20}$ Secretory function was assessed in the basal state without the addition of secretagogues and as the maximum secretory current minus the basal secretory current after the serosal addition $(1 \mathrm{mmol} / \mathrm{l})$ of the stable muscarinic (M1/M2) agonist bethanechol or dibutyryl cyclic adenosine monophosphate (AMP). The absorptive function of the segments was monitored by the mucosal addition of $28 \mathrm{mmol} / 1$ glucose (balanced osmotically by the serosal addition of $28 \mathrm{mmol} / \mathrm{l}$ mannitol) which generated, by $\mathrm{Na}^{+}-$coupled electrogenic glucose transfer, a transfer short circuit current.

\section{PLASMA VITAMIN A ESTIMATION}

The concentration of vitamin A in the plasma of the various experimental groups was estimated by a modification by Robinson ${ }^{21}$ of the techniques of Grys ${ }^{22}$ and Bayfield and Cole. ${ }^{23}$

\section{MATERIALS}

All the chemicals were purchased from Sigma Chemical, Poole, England. The cubed vitamin A deficient diet (ssDii) was purchased from SDS Diets, England, and the normal control diet CRM from Labsure, London. The soluble vitamin A used in the drinking water (Rovamix, A concentrations in various nutritional groups. Blood samples were collected from the inferior vena cava in anesthetised rats. Results are mean $(S E)$

\begin{tabular}{ll}
\hline & $\begin{array}{r}\text { Plasma vitamin } A \\
(\mu g / l)\end{array}$ \\
\hline Group 1 $(\mathrm{n}=14)$ & $224(56)^{\mathrm{a}}$ \\
Group 2 $(\mathrm{n}=6)$ & $355(36)^{\mathrm{b}}$ \\
Group 3 $(\mathrm{n}=11)$ & $792(77)^{\mathrm{c}}$ \\
Group 4 $(\mathrm{n}=11)$ & $996(60)^{\mathrm{d}}$ \\
Group 5 $(\mathrm{n}=8)$ & $927(80)^{\mathrm{c}}$ \\
\hline Kruskal-Wallis analysis of \\
variance followed by \\
Conover's multiple $t$ test were \\
used to identify the significant \\
values. a $v \mathrm{c} ;$ a $v$ d; a ve; b $v \mathrm{~d}$, \\
and b $v$ e are all significant at \\
$\mathrm{p}<0.001 ; \mathrm{b} v \mathrm{c}$ is significant at \\
$\mathrm{p}<0.002$.
\end{tabular}

TABLE III Basal currents ( $\mu A / \mathrm{cm}^{2}$ serosal area) of unstripped jejunum, proximal ileum, and distal ileum in various nutritional groups. Results are mean $(S E)$

\begin{tabular}{|c|c|c|c|}
\hline & \multicolumn{3}{|c|}{ Basal I currents $\left(\mu A / \mathrm{cm}^{2}\right)$} \\
\hline & fejunum & Ileum & Distal ileum \\
\hline $\begin{array}{l}\text { Group 1 } \\
\text { Group 2 } \\
\text { Group 3 } \\
\text { Group 4 } \\
\text { Group 5* }\end{array}$ & $\begin{array}{l}63(4)^{\mathrm{a}}(\mathrm{n}=18) \\
66(6)^{\mathrm{d}}(\mathrm{n}=9) \\
64(5)^{\mathrm{s}}(\mathrm{n}=14) \\
94(7)^{\mathrm{i}}(\mathrm{n}=17) \\
92(3)^{\mathrm{m}}(\mathrm{n}=30)\end{array}$ & $\begin{array}{l}45(4)^{\mathrm{b}}(\mathrm{n}=9) \\
40(4)^{\mathrm{c}}(\mathrm{n}=9) \\
53(3)^{\mathrm{n}}(\mathrm{n}=14) \\
64(7)^{\mathrm{k}}(\mathrm{n}=17) \\
47(3)^{\mathrm{n}}(\mathrm{n}=24)\end{array}$ & $\begin{array}{l}48(4)^{c}(n=19) \\
36(1)^{\prime}(n=9) \\
57(4)^{\prime}(n=14) \\
60(4)^{\prime}(n=17) \\
33(2)^{0}(n=30)\end{array}$ \\
\hline
\end{tabular}

Kruskal-Wallis analysis of variance followed by Conover's multiple $t$ test were used to identify the significant values. a $v$ j; a $v$ $\mathrm{m} ; \mathrm{c} v 0$ are all significant at $\mathrm{p}<0.001 ; \mathrm{b} v \mathrm{k} ; \mathrm{c} v \mathrm{f} ; \mathrm{c} v \mathrm{l}$ are all significant at $p<0.05$. ${ }^{\star}$ Data from Young and Levin. ${ }^{14}$

\section{FOOD INTAKE}

Table I gives the food intake of group 1 for days $1,10,20,30$ and 40 on the vitamin A deficient diet. There was an increase of $1 \cdot 2$-fold from day 20 to day 40 . For comparison the food intake of the rats fed the normal control diet (CRM, Labsure) is shown for day 40 , it being approximately 2.7 times greater than that of the vitamin A deficient group. It should be noted that for groups 4 and 5, who were fed the normal CRM diet, group 4 represents a chronically undernourished group compared with group 5 (as on day 40 , for example, group 4 rats received only $9 \mathrm{~g}$ CRM diet/day while those in group 5 averaged $24 \mathrm{~g} /$ day). Group 4 rats on $9 \mathrm{~g} /$ day would have an average daily vitamin $A$ intake of 135 IU vitamin A while those on $24 \mathrm{~g}$ (group 5) would have an intake of $360 \mathrm{IU} / \mathrm{day}$.

The plasma concentrations of vitamin A for the five groups are given in Table II. The rats on the vitamin deficient diet (group 1) had the lowest concentrations. The average daily requirement for vitamin $A$ in adult rats has been estimated as 40-80 IU. ${ }^{13}$ The vitamin A deficient rats fed 80 IU vitamin A/day (group 2) showed an increased plasma vitamin A concentration, but this was not significantly different from group $1(\mathrm{p}>0.05)$, while those fed 240 IU vitamin A/day (group 3) had a vitamin A concentration approximately 3.5 times greater $(p<0.001)$ than group 1. Moreover, the concentration for this group was not significantly different from that in rats pair fed the normal CRM diet (group 4) and the age matched rats fed the normal CRM diet ad libitum (group 5). Thus feeding $80 \mathrm{IU}$ vitamin $\mathrm{A} /$ day in the drinking water does not satisfactorily restore the plasma vitamin A state of the vitamin deficient rats to normal, but giving $240 \mathrm{IU}$ vitamin A/day does.

\section{INTESTINAL PHYSICAL AND BIOELECTRIC PARAMETERS}

Several basic physical and bioelectric parameters were measured in the intestines of the vitamin deficient rats (group 1) and the vitamin deficient rats supplemented with $240 \mathrm{IU}$ vitamin A/day (group 3). Because there was no significant difference between the groups for total intestinal length or weight of jejunal, proximal ileal, and terminal ileal segments per $\mathrm{cm}^{2}$ serosal area and

\section{VITAMIN A PLASMA LEVELS}


TABLE IV Maximum secretory currents $\left(\mu A / \mathrm{cm}^{2}\right.$ serosal area) induced by $1 \mathrm{mmol} / \mathrm{l}$ serosal bethanechol in unstripped jejunum, proximal ileum, and distal ileum from various nutritional groups. Results are mean $(S E)$

\begin{tabular}{|c|c|c|c|}
\hline & \multicolumn{3}{|c|}{$\begin{array}{l}\text { Bethanechol: maximum minus basal secretory } \\
\text { current }\left(\mu \mathrm{A} / \mathrm{cm}^{2}\right)\end{array}$} \\
\hline & fejunum & Ileum & Distal ileum \\
\hline Group 1 & $104(10)^{a}(n=10)$ & $138(11)^{b}(n=11)$ & $121(12)^{c}(n=11)$ \\
\hline Group 2 & $122(9)^{d}(n=9)$ & $141(8)^{c}(n=9)$ & $107(11)^{r}(n=9)$ \\
\hline Group 3 & $56(8)^{8}(n=6)$ & $101(13)^{\mathrm{h}}(\mathrm{n}=6)$ & $91(5)^{i}(\mathbf{n}=9)$ \\
\hline Group 4 & $179(17)(n=9)$ & $247(13)^{\mathrm{k}}(\mathrm{n}=9)$ & $137(9)^{1}(\mathbf{n}=9)$ \\
\hline Group 5* & $59(6)^{m}(n=12)$ & $140(10)^{n}(n=9)$ & $63(3)^{\circ}(n=10)$ \\
\hline
\end{tabular}

Kruskal Wallis analysis of variance followed by Conover's multiple $t$ test were used to identify the significant values. a $v \mathrm{~m}$; $v \mathrm{k} ; \mathrm{c} v 0$ are all significant at $\mathrm{p}<0.001 ; \mathrm{a} v \mathrm{j}$ is significant at $\mathrm{p}<0.002 ; \mathrm{a} v \mathrm{~g}$ is significant at $\mathrm{p}<0.01 ; \mathrm{c} v$ i is significant at $\mathrm{p}<0.05$ * $\mathrm{Data}$ from Young and Levin ${ }_{1425}$

for basal potential difference, these have not been shown. The data for the basal current are given in Table III. While no significant differences were found between the vitamin deficient (group 1) and the vitamin deficient pair fed groups (groups 2 and 3) a significant rise in the jejunal basal current was evident in group 4 $(+49 \%, \mathrm{p}<0.001)$ and group $5(+46 \%, \mathrm{p}<0.001)$ compared with group 1 . In the ileum no significant differences were found between the vitamin deficient rats (group 1) and other control groups 2 and 3, but the pair fed rats in group 4 showed a significant increase $(+42 \%, \mathrm{p}<0.005)$. The tissue resistance for the jejunum and distal ileum was not significantly different between groups 1 and 3 but that of the proximal ileum was significantly lower by approximately $22 \%$ $(\mathrm{p}<0.001)$ in the vitamin deficient group (group $1, \mathrm{n}=19$ mean (SE) $57(5) \mathrm{ohms} / \mathrm{cm}^{2}$ serosal area compared with group $3, \mathrm{n}=14,73(5) \mathrm{ohms} / \mathrm{cm}^{2}$ serosal area).

SECRETORY CURRENTS INDUCED BY BETHANECHOL The secretory currents induced in the jejunum, proximal ileum, and distal ileum by serosal bethanechol in the five groups are given in Table

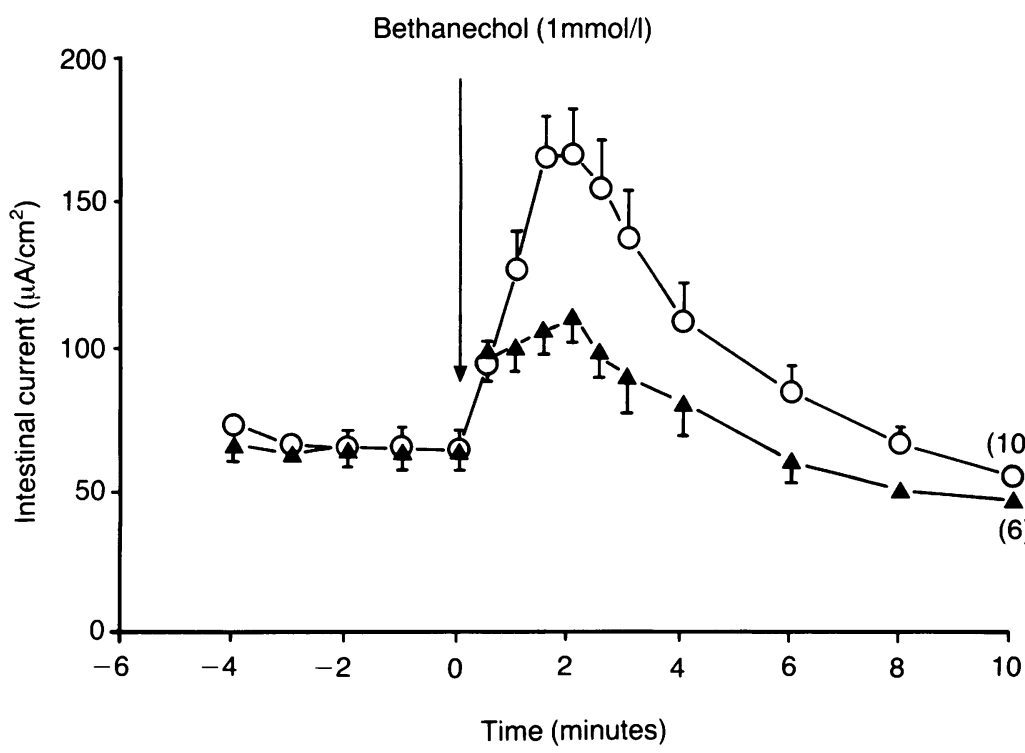

Figure 1: Time course of the response of the intestinal current to the serosal addition (at time 0) of bethanechol ( 1 mmol/l) to jejunum from vitamin A deficient rats (group $1, \bigcirc$ ) and from vitamin A deficient rats supplemented with 240 IU vitamin A/day (group $3, \Delta)$ ). Results are plotted as the mean with standard error bars. Where there are no bars the standard error is included in the symbol size. Number of rats in parentheses.
IV. The time course of the response for the jejunum is shown in Figure 1. Comparing the vitamin A deficient (group 1) with the deficient rats supplemented with $240 \mathrm{IU}$ vitamin A (group 3) the maximum minus basal secretory current induced in the jejunum was $86 \%$ greater $(\mathrm{p}<0.001)$, that in the proximal ileum was $37 \%$ greater (but not significant), while that in the distal ileum was $33 \%$ greater $(\mathrm{p}<0.05)$. Even in the vitamin A deficient animals supplemented with $80 \mathrm{IU}$ vitamin A (group 2) the maximum minus basal secretory current of the jejunum $(+$ $118.5 \%, \mathrm{p}<0.001)$ and proximal ileum $(40 \%$, $\mathrm{p}<0.02$ ) was significantly greater than that in group 3. The CRM diet pair fed rats (group 4) showed enhancement of bethanechol secretion brought about by chronically reduced food intake when compared to the maximum minus basal secretory current induced in the rats fed ad libitum on the CRM diet (group 5). The secretory current of the jejunum in group 4 rats was $203 \%$ greater $(\mathrm{p}<0.001)$, in the proximal ileum $76 \%$ greater $(\mathrm{p}<0.001)$, and in the distal ileum $117 \%$ greater $(\mathrm{p}<0.001)$ than that in group 5. That in group 3 rats was not significantly enhanced in the jejunum and proximal ileum, but in the distal ileum it was significantly greater $(44 \% \mathrm{p}<0.001)$ than in group 5.

\section{SECRETORY CURRENTS INDUCED BY DIBUTYRYL CYCLIC AMP}

The secretory currents induced by dibutyry cyclic AMP in the jejunum, proximal ileum, and distal ileum in the five groups are given in Table $\mathrm{V}$. The time course of response for the distal ileum is shown in Figure 2. An increase in the maximum minus basal secretory current was observed only in the terminal ileum $(+40 \%$, $\mathrm{p}<0.01$ ) when the vitamin deficient rats (group 1) were compared with the vitamin deficient supplemented with $240 \mathrm{IU}$ vitamin A/day (group 3 ); the secretory currents of the jejunum and proximal ileum were not significantly different. The currents of the CRM pair fed rats (group 4) showed increases in the jejunum $(+33 \%$, $\mathrm{p}<0.05)$ when compared with those in the rats fed ad libitum with the CRM diet (group 5). The currents for group 3 rats were not significantly different from those of group 4, indicating that feeding 240 IU vitamin $\mathrm{A} /$ day restored the intestinal function to the level of the rats with normal vitamin A concentrations but on a reduced food intake.

TABLE V Maximum secretory currents $\left(\mu A / \mathrm{cm}^{2}\right.$ serosal area) induced by $1 \mathrm{mmol} / \mathrm{l}$ serosal dibutyryl cyclic AMP in unstripped jejunum, proximal ileum, and distal ileum from various nutritional groups. Results are mean $(S E)$

\begin{tabular}{|c|c|c|c|}
\hline & \multicolumn{3}{|c|}{$\begin{array}{l}\text { Dibutyryl cyclic } A M P: \text { maximum minus basal } \\
\text { secretory current }\left(\mu A / \mathrm{cm}^{2}\right)\end{array}$} \\
\hline & Fejunum & Ileum & Distal ileum \\
\hline $\begin{array}{l}\text { Group } 1 \\
\text { Group } 3 \\
\text { Group } 4 \\
\text { Group 5` }\end{array}$ & $\begin{array}{l}68(12)^{\mathrm{a}}(\mathrm{n}=8) \\
84(12)^{\mathrm{d}}(\mathrm{n}=8) \\
96(11)^{\mathrm{g}}(\mathrm{n}=8) \\
72(5)^{\mathrm{i}}(\mathrm{n}=19)\end{array}$ & $\begin{array}{c}85(10)^{\mathrm{b}}(\mathrm{n}=8) \\
113(8)^{\mathrm{c}}(\mathrm{n}=8) \\
107(11)^{\mathrm{b}}(\mathrm{n}=8) \\
125(5)^{\mathrm{k}}(\mathrm{n}=15)\end{array}$ & $\begin{array}{c}158(11)^{c}(n=8) \\
113(6)^{f}(n=8) \\
88(12)(n=8) \\
56(3)^{\prime}(n=10)\end{array}$ \\
\hline
\end{tabular}
$v \mathrm{i} ; \mathrm{c} v 1$ are all significant at $\mathrm{p}<0.001 ; \mathrm{c} v \mathrm{f}$ is significant at $\mathrm{p}<0.01$. ${ }^{\star}$ Data from Young and Levin. ${ }^{14} 25$ 


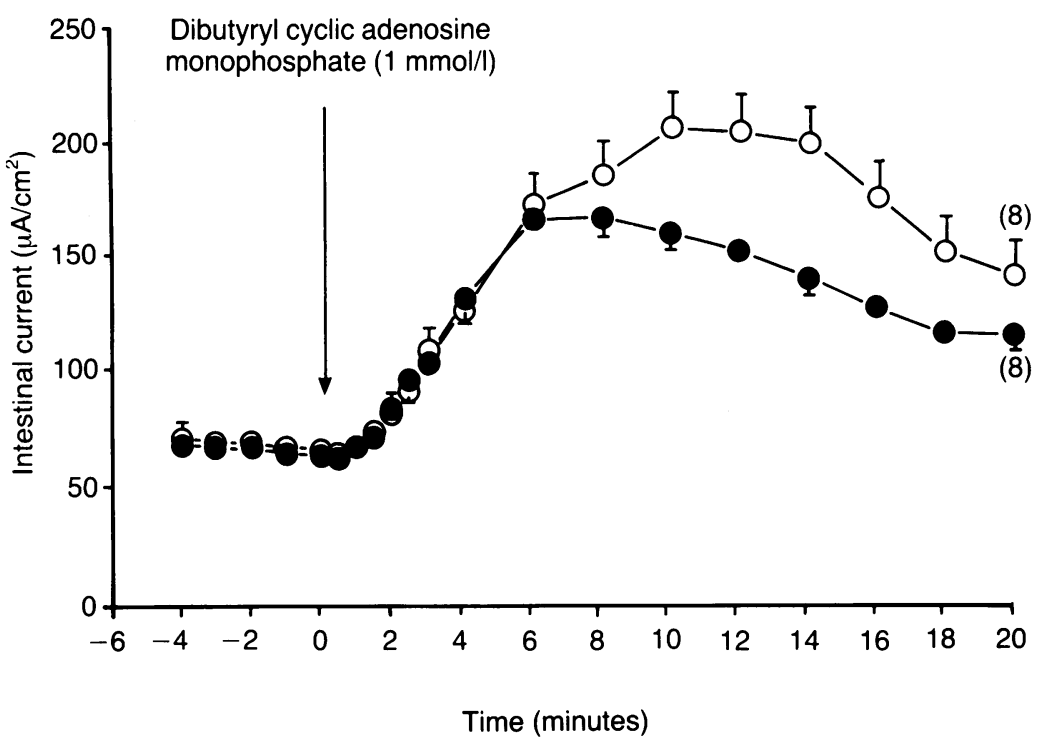

Figure 2: Time course of the response of the intestinal current to the serosal addition (at time 0) of dibutyryl cyclic AMP ( 1 mmolll) to distal ileum from vitamin A deficient rats (group $1, \bigcirc)$ and from vitamin A deficient rats supplemented with 240 IU vitamin A/day (group 3, O). Results are plotted as the mean with standard error bars. Where there are no bars the standard error is included in the symbol size. Number of rats in parentheses.

\section{ELECTROGENIC GLUCOSE TRANSFER}

The transfer currents induced by the addition of $28 \mathrm{mmol} / \mathrm{l}$ glucose to the mucosal fluids of the jejunum, proximal ileum, and terminal ileum from the various nutritional groups are shown in Table VI. No significant difference was observed for the maximum minus basal transfer currents between the vitamin A deficient rats (group 1) and the vitamin deficient rats supplemented with 240 IU vitamin A/day (group 3). In group 4 the values for the proximal ileum $(+163 \%, \mathrm{p}<0.01)$ and the terminal ileum $(+39 \%, \mathrm{p}<0.05)$ were significantly greater than the values for group 5 fed ad libitum.

\section{Discussion}

The results show that vitamin A deficiency has complex effects on the secretory functions of the small intestine when assessed in vitro. While the basal intestinal current, which is known to be mainly electrogenic $\mathrm{Cl}^{-}$secretion, ${ }^{14}{ }^{15}$ seems to be unaltered, the maximum minus basal current induced by bethanechol, a stable muscarinic M1/M2 agonist, was significantly greater in jejunum and so was that induced by dibutyryl cyclic AMP in the distal ileum of the vitamin A

TABLE VI Maximum transfer currents $\left(\mu A / \mathrm{cm}^{2}\right.$ serosal area) induced by $28 \mathrm{mmol} / \mathrm{l}$ mucosal glucose: $28 \mathrm{mmol} / \mathrm{l} \mathrm{serosal}$ mannitol in unstripped jejunum, proximal ileum, and distal ileum from various nutritional groups. Results are mean $(S E)$

\begin{tabular}{|c|c|c|c|}
\hline & \multicolumn{3}{|c|}{$\begin{array}{l}\text { Glucose: maximum minus basal transfer current } \\
\left(\mu \mathrm{A} / \mathrm{cm}^{2}\right)\end{array}$} \\
\hline & fejunum & Ileum & Distal ileum \\
\hline $\begin{array}{l}\text { Group 1 } \\
\text { Group 2 } \\
\text { Group 3 } \\
\text { Group 4 } \\
\text { Group 5^ }\end{array}$ & $\begin{array}{r}58(12)^{\mathrm{a}}(\mathrm{n}=9) \\
89(10)^{\mathrm{d}}(\mathrm{n}=9) \\
40(11)^{\mathrm{s}}(\mathrm{n}=6) \\
213(20)^{\prime}(\mathrm{n}=9) \\
-\end{array}$ & $\begin{array}{c}62(10)^{b}(n=10) \\
81(12)^{c}(n=9) \\
35(6)^{h}(n=6) \\
289(24)^{\mathrm{k}}(n=9) \\
110(3)^{\mathrm{m}}(\mathrm{n}=40)\end{array}$ & $\begin{array}{l}46(6)^{c}(\mathrm{n}=10) \\
35(4)^{l}(\mathrm{n}=9) \\
61(5)^{\prime}(\mathrm{n}=6) \\
79(10)^{\mathrm{l}}(\mathrm{n}=9) \\
57(4)^{\mathrm{n}}(\mathrm{n}=30)\end{array}$ \\
\hline
\end{tabular}

deficient rat. Bethanechol induced secretion is mainly electrogenic $\mathrm{Cl}^{-}$in the jejunum, ${ }^{14}$ but there is some electrogenic bicarbonate secretion in the ileum. ${ }^{15}$ Previous studies on the distal ileum $^{25}$ have shown that this area has significantly less secretory and absorptive capacity than the proximal ileum and did not adapt to starvation. ${ }^{26}$ The former finding ${ }^{25}$ is confirmed in the present study when the data of the distal ileum are compared with that of the proximal ileum in group 5 rats, those fed the normal control diet (CRM, Labsure) ad libitum. The basal current and the bethanechol stimulated, dibutyryl cyclic AMP stimulated, and glucose stimulated maximum minus basal currents of the distal ileum were clearly less than those of the proximal ileum. This pattern is completely disrupted in the vitamin A deficient group (group 1) where the basal current and the bethanechol induced and glucose induced maximum minus basal currents of the distal ileum are not lower than those of the proximal ileum. Even in the case of the dibutyryl cyclic AMP induced current, that of the distal ileum in the vitamin deficient group is actually greater than in the proximal ileum. Vitamin A deficiency thus alters dramatically the balance between the distal and proximal ileum. In a previous study we presented evidence to suggest that one property of the distal ileum may be its 'chemosensing' function..$^{25}$ Whether vitamin A deficiency also interferes with this putative distal ileal function is a question to be answered in further studies.

It is interesting that the alterations in intestinal function brought about by vitamin A deficiency in the rat seem to be selective for the secretory function, for no change could be found in the absorptive electrogenic transfer of glucose. The only other data on the absorptive function of the vitamin A deficient rat is a brief note by Kancha and Anasuya, ${ }^{12}$ who reported that the in vitro duodenal transfer of calcium and the jejunal transfer of oxalate were enhanced compared with those of control intestine from pair fed rats. Their rats, however, were made vitamin A deficient over 84 days compared with the 40 days in our study. It is not known whether this increase in duration of the deficient state is an important difference between the studies. Only two other investigations have examined secretory function in the gastrointestinal tract of vitamin A deficient rats. The basal transmural gastric potential difference was not altered significantly in vitamin $\mathrm{A}$ deficient rats, ${ }^{27}$ but unfortunately no measurements were made in the rats stimulated to secrete acid, which is probably the more important measurement. In the case of the salivary gland ${ }^{28}$ impaired secretion of saliva was found during the induction of rapid, synchronous vitamin A deficiency.

Vitamin A deficiency in the rat seems to induce an increase in jejunal electrogenic secretion (chloride) when activated by bethanechol and in the distal ileum when activated by dibutyryl cyclic AMP. Feeding vitamin $\mathrm{A}$ in the drinking water to vitamin $\mathrm{A}$ deficient rats prevented the changes. This is the first clear cut demonstration that vitamin A deficiency alone can enhance the secretory function of the small intestine. This enhanced 
secretory activity observed in the rat offers an explanation for the well known relation between vitamin A deficiency and diarrhoea found in humans. ${ }^{23}$

Acknowledgement is given to the Medical Research Council for financial support.

1 Roel O. Vitamin A physiology. FAMA 1970; 214: 1097-102. Feachem RG. Vitamin A deficiency and diarrhoea - a review of interrelationships and their implications for the control of xeropthalmia and diarrhoea. Trop Dis Bull 1987; 84: R1-16.

3 West KP, Howard GR, Sommer A. Vitamin A and infection public health implications. Annu Rev Nutr 1989; 9: 63-86.

4 DeLuca L, Little EP, Wolf G. Vitamin A and protein synthesis by rat intestinal mucosa. $\mathcal{F}$ Biol Chem 1969; 244 701-8.

5 Corey JE, Hayes KC. Cerebrospinal fluid pressure, growth and hematology in relation to retinol status of the rat in acute vitamin A deficiency. 7 Nutr 1972; 102: 1585-94.

6 DeLuca L, Maestri N, Bonanni F, Nelson D. Maintenance of epithelial cell differentiation: the mode of action of vitamin epithelial cell differentiation:
A. Cancer 1972; 30: 1326-31.

7 Ahmed F, Jones DB, Jackson AA. The interaction of vitamin A deficiency and rotavirus infection in the mouse. $\mathrm{Br} \mathcal{F}$ Nut 1990; 63: 363-73.

8 Zile M, Bunge EC, DeLuca HF. Effect of vitamin A deficiency on intestinal cell proliferation in the rat. $\mathcal{F}$ Nutr $1977 ; 107$ $552-60$.

9 Zachman RD. The stimulation of RNA sythesis in vivo and in vitro by retinol (vitamin A) in the intestine of vitamin $A$ deficient rats. Life Sci 1967; 6: 2207-13.

10 Zile M, DeLuca HF. Vitamin A and ribonucleic acid synthesis in rat intestine. Arch Biochem Biophys 1970; 140: 210-4.

11 Singh K, Krishnakantha R, Krishnakantha TP. Intestinal epithelial cell alkaline phosphatase and $\mathrm{Na}^{+}, \mathrm{K}^{+}$-ATPase activity in albino rats in retinol deficiency. Nutr Rep In 1987; 35: 937-80.

12 Kancha R, Anasuya A. Vitamin A deficiency in rats enhance intestinal transport of calcium and oxalate in vitro. Int $\mathcal{f}$ Vitam Nutr Res 1989; 59: 236-7.

13 Olson JA. Physiological and metabolic basis of major signs of vitamin A deficiency. In Bauernfeind JC, ed. Vitamin A deficiency and its control. Orlando FL: Academic press, 1986 $19-65$.
14 Young A, Levin RJ. Diarrhoea of famine and malnutrition: investigations using a rat model. 1. Jejunal hypersecretion induced by starvation. Gut 1990; 31: 43-53.

15 Young A, Levin RJ. Diarrhoea of famine and malnutrition: investigations using a rat model. 2. Ileal hypersecretion induced by starvation. Gut 1990; 31: 162-9.

16 Levin RJ, Nzegwu C, Young A. Proximal colon secretion in fed and fasted rats. $\mathcal{F}$ Physiol (Lond) 1987; 396: 33P

17 Nzegwu C, Pereira MMC, Warren MA, Levin RJ, Young A Acute and chronic undernutrition and their effects on colonic secretion. Proc Nutr Soc 1988; 47: 164A.

18 Levin RJ, Parker AJ. Rectal electrogenic secretion - is it a putative indicator of intestinal secretory status induced by nutritional deprivation in the rat? Exper Physiol 1990; 75: nutritional.

19 Levin RJ, Nzegwu C. Vitamin A deficiency and its effects on in vitro jejunal and ileal electrogenic secretion in the rat. $\mathcal{J}$ in vitro jejunal and ileal electrog

20 Baldwin D, Levin RJ. Electrogenic currents induced by secretagogues and glucose across proximal and distal rat duodenum and jejunum in vitro. IRCS Med Sci 1985; 13 269-70.

21 Robinson ME. Retinoids in organ culture of the cheek pouch and in other tissues of the Syrian hamster (mesocricetus auratus). M Sc Guelph, Ontario: University of Guelph. (thesis.)

22 Grys S. An improved and accurate procedure for the determination of vitamin A. Analyst 1975; 100: 637-9.

23 Bayfield RF Cole ER. Colorimetric estimation of vitamin A with trichloracetic acid. Methods Enzymol 1980; 67: 189203.

24 Theodorsson-Nordheim E. Kruskal-Wallis test: BASIC computer program to perform non-parametric one-way analysis of variance and multiple comparisons on ranks of independent samples. Comput Methods Programs Biomed 1986; 23 : 57-62.

25 Young A, Levin RJ. The rat distal ileum has a reduced absorptive and secretory capacity compared with proximal leum - is to facilitate its chemosensing function? $Q \mathcal{F} E x$ Physiol 1989; 74:561-3.

26 Levin RJ, Young A. Proximal but not distal rat ileum shows adaptive responses to starvation. $\mathcal{F}$ Physiol (Lond) $1990 ; 420$ : adaptiv.

27 Sommer H, Kasper H. Gastric transmural potential difference in rats fed with a retinol free diet. Acta Hepatogastroenterol 1978; $25: 136-8$

28 Anzano MA, Lamb AJ, Olson JA. Impaired salivary gland secretory function following the induction of rapid, synchronous vitamin A deficiency in rats. $\mathcal{F}$ Nutr 1981; 111: 496-504. 